可祝化情衼 Vol. 12 Suppl. No.1（1992年 7 月）

32 生体内流れの計即一尃用ハードゥェアによるリアルタイム計矵一

株応用計测研究所清水雅夫 ${ }^{\circ}$ 、桑島茂純

A Measurement of Blood Flow Velocity by using Real-Time Cross-Correlation Hardware and High-Rate VCR

Masao SHIMIZU, Shigesumi KUWASHIMA

This report is on applications of our measurement system which can measure and display velocity/displacement vectors in real-time by processing the $B / W$ video signal of the objective image. It uses a 2-dimensional cross-correlation technique of binary video data to determine vectors. The measuring rate is $1 / 60 \mathrm{sec}$ for 16 templates (areas).

The first one is on a measurement of a blood flow velocity which changes its value synchronizing with the heart beat. The recorded video image is captured by using a high-rate VCR (1000 [pictures/sec]) and a microscope $(\times 40)$. The image is that of micro blood vessels located in mesentery of a rat. Then we introduce some data processing techniques depending on the measuring method.

In Addition, we present a measurement of a micro scale movement of a plant. By using the laser speckle pattern, the system can measure micron-meter order displacement. Horizontal movement of a plant is presented.

\title{
1.はじめに
}

TVカメラまたはビデオ再生画像から、相関法によりリアルタイムで速度／変位ベクトルを测 定できる画像計測システムを既に開発した。これは、相関処理に専用ハードゥェアを使用した あので、画面内最大 16 所の同時計測が可能である。計測結果は画面に重稀わせて実時間表 示され、またホストコンピュータに送出す可能である(4)(5)。

本報告では、この計測システムを使用した計測例を紹介する。高速VTRに記録し、その再生 画像を用いて血流速度分布の時間変化を計測した。さらに、植物の微小な動きを計測した。レ ーザスペックルを変位マーカとすることにより、非接触で微小変位計測を行なった。

また、計測画像によっては本計測システムで用いている相関法に起因するノイズが計測デー 夕に含まれる場合があるが、その低減方法についてす述べる。

\section{2. 血流速度分布の計矵}

\section{2-1 画像の取得方法}

近年、医用診断や研究に画像処理及び画像計測が用いられるようになってきた。それは、撮 影対象の拡大、撮影(可視化)手法の確立、各種画像処理装置の発達などによるすのであるが、 静止画像を対象としたものが一般的である。しかし、生体は本来動いており、そのダイナミッ クな内部変化も計測されはじめている(1)(2)。

計測に用いた画像は、ラット腸間膜上微小血管の顕微鏡画像（倍率40倍）を高速VTRに 1000 [frame/sec] で記録したものである。その再生画像（30[frame/sec]）を用いて計測した。再

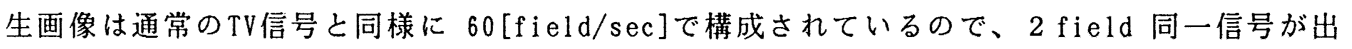
力されることになる。fig. 1 に再生画像を示す。

\section{2-2 計矵方法}

本計测システムは入力画像を 2 值化後、相関処理を行なう。 2 次元的なテンプレート・マッ 
チング法にて 2 画面間の変位量を算出し、これを 2 画面間時間における変位即ち速度とする。 変位量は画素分解能以上に補間される。相関処理を行い一致検索する螌囲は、水平 16 [dot]、 垂直 16 [1 ine ]であるが、検索範囲の中心は過去の計測結果を用いて予测設定することすできる。

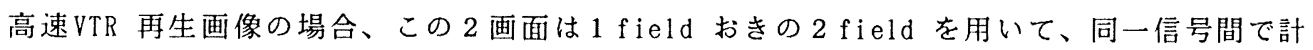
测を行なわないようにする。このときの計测周期は 4 field となる。テンプレート領域は流れ 方向に長い $60 \times 16$ [dot] $(60[\mathrm{dot}] \times 8$ [1 ine])とした。実長では $22 \times 6[\mu \mathrm{m}]$ である。fig. 1 に示す 测定線上を $10[\mathrm{dot}](3.8[\mu \mathrm{m}])$ おきに計測した。

全検索範囲について相関係数を算出後、その最大値及び係数形状の平坦さ（最大值一周辺值 の平均）を調べる。こ㞦が設定值より小さい場合、検索範囲の中心位置を初期位置にリセット させた。係数ピークを見失った位置にホールドさせることもできるが、この計測の場合にはト レーサである血球の形状変形があるため偽ピークに到達する可能性が高い。偽ピークを追跡す ると以後の計测值は意味のない大きな值になってしまう。検索範囲が比較的小さいので検索範 囲の中心が初期位置にリセットされた場合、係数ピーク位置に到達するのに何回かの計测周期 を要することがある。この様子は計測データ内のステータスに示される。これらの処理は全て 計测装置内で行なわれ、入力画像の $1 \mathrm{field}$ が終了した時点で計测結果が得られる。

\section{2-3 計矵データに含まれるノイズ低减の方法}

計測に用いた画像は明確なトレーサを含まず、濃淡パターンが移動しているようなるのであ る。こ机を 2 值化することによるパターン・エッジの不確定、血球自体の変形、高速VTR 再生 画像に含まれるビデオノイズなどの影響で、係数ピーク值はそれほど大きくない。そのため、 fig. 2(a)に示すように、速度べクトルが細かく変動しているように計測される。また初期位置 にリセットされた場合には、大きなスパイクノィズとなって記録さ机てしまう。

これらのノイズを除去する目的でつぎのような処理を行なった。

(1) 検索範囲の中心が初期位置にリセットされたことが榆出されたら（フィールド番号 $\mathrm{f} 1$ ）、 その後係数ピークに追従できたフィールド（f2）をさがす。f1からf2-1までのデータをf1-1と $\mathrm{f} 2$ の平均に置き換える。

(2) 突発的に係数ピークに追従できなかったフィールド（f1）を捜す。その後係数ピークに追 従できたフィールド（f2）をさがす。f1からf2-1までのデータをf1-1とf2の平均に置き換える。 (3) 前後のフィールドに対して計测值の大きさが凸または凹的に一定值以上变化しているフィ ールド（f1）を捜す。f 1 のデータをf 1-1とf1+1の平均に置き換える。

(4) 同一再生画像を複数回計測して(1)から(3)の処理をした後、加算平均する。画像中に記録さ れている心電マーカを同時に計測して、これを時間軸合わせに使用する。

(5) 最後にディジタルフィルタで高周波成分を除去する。再生画像における計測波形の基本周 波数が $0.18 \mathrm{~Hz}$ 程度だったので、カットオフ周波数 $0.25 \mathrm{~Hz}$ の 21 次 I 型直線位相 FIRフィルタを使 用した。

4 回計測して加算平均し、(5)の処理を行なった結果をfig. 2(b)に示す。(1)から(5)までの処理 の中で最む效果があるのは(4)である。

\section{2-1 計矵結果}


fig. 3 に計測結果を示す。グラフ奥に示したマーカは、同時に画像に記録された心電信号で ある。主流には心電信号に同期した拍動がみられ、分岐点後流では流速、拍動とむ小さくなっ ていることがわかる。fig. 4 に $\mathrm{t}=0.10[\mathrm{sec}]$ 及び $\mathrm{t}=0.22[\mathrm{sec}]$ における速度分布を示す。 1 回 の計測から得られた速度はテンプレート領域内速度分布と相関計算に有効だったパターン密度 との関数だが、加算平均処理を行なっているので、テンプレート領域内平均速度を示している と考えられる。

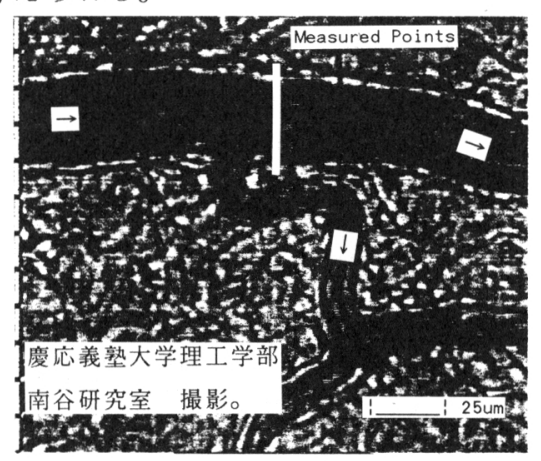

fig. 1 The Original Image of blood vessel

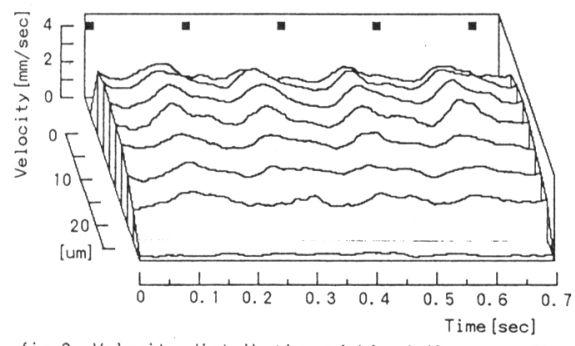

fig. 3 Velocity distribution of blood flow vs. Time

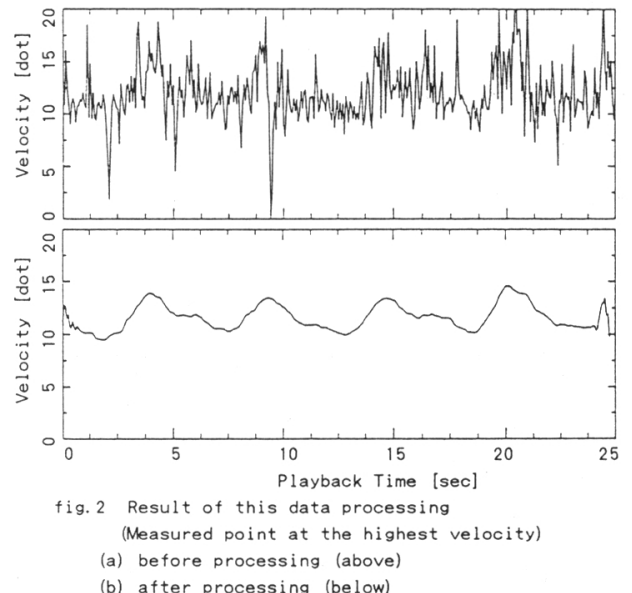

b) after processing (below)

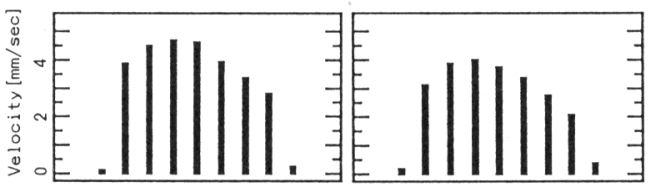

fig. 4 Velocity distribution at

(a) $t=0.10$ [sec] (left)

(b) $t=0.22$ [sec] (right)

\section{3. 植物の微小な動きの計㳔}

\section{3-1 計矵方法}

He-Ne レーザをビームエクスパンダにより広げ植物に固定した紙に当てた。 CCDカメラはソ ニーXC-77RR( 2/3インチ白黒)で、撮影レンズ系は使用しなかった。レーザのビーム径をDe、 紙から CCD素子までの距離を $\mathrm{Rb}$ 、波長を入とするとスペックル画像の平均粒子径（水平）は、

$$
\frac{\lambda R \mathrm{Rb}}{\mathrm{De}}=\frac{632.8[\mathrm{~nm}] \times 350[\mathrm{~mm}]}{8[\mathrm{~mm}]}=27.7[\mathrm{um}]=2.4[\mathrm{dot}]
$$

レーザが点光源（非平行光）で撮影レンズ系がない場合、点光源までの距離をRs、対象の移動 をレとすると観测されるスペックル画像の移動（水平）は

$$
\left(\frac{R b}{R s}+1\right) \times V=3.37 \times V
$$

これらを適切に選定して計測を行なった (5)。fig. 5 に示す系を他に動くものがない明るい部屋 に入れ、 1 秒に 1 回のサンプリングで10分間計測を行なった。計測のはじめに参照画像を登録 
し、変位ベクトルを計测した。係数ピークが一定値以下に下がった場合には、参照画像を更新 するようにした。

\section{3-2 計别結果}

fig. 6 に計测結果を示す。結果の処理は行なっていない。水平方向に 2 分から 3 分周期の変 動がみられる。垂直方向 4 分20秒付近の突然の変化はレーザ・ホッピングと考えられる。

\section{3-3 植物内部変化について}

fig. 5 において、植物に直接レーザを当ててスペックル画像を観察すると、植物内部の変化 を見ることができる。これを高速VTR で記録再生してみたが、流れは確認できなかった。時間 軸の拡大率 $(1000 / 30)$ の不足、高速VTR の空間分解能 $(256 \times 192$ [dot])の不足、異方向 - 異深度 の合成画像になっていた、などが原因として考えられる。

\section{4.まとめ}

画像計測の場合、取得された画像及び計測方 法の性質を有効に用いることで効果的な計測・ 処理ができる。本計測システムの場合には、装 置の設定を変更して一連の計测結果を得るのに

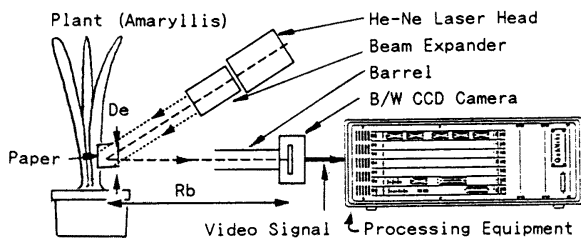

fig. 5 The system of the measurement

要する時間が計测画像の再生時間と等しいので、 最適な設定条件を選定するのは、困難なことで はない。今後は、本計测システムの動的特性な どについて報告する予定である。

\section{5. 謝辞}

血流速度分布測定の機会をいただき、また高 速VTR 画像を御提供くださった慶応義塾大学 理工学部 南谷晴之教授、岡田英史助手に感謝 致します。

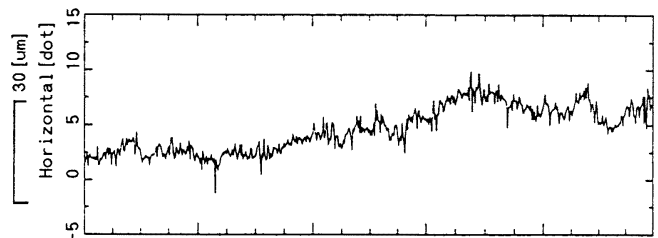

\section{6. 参考文献}

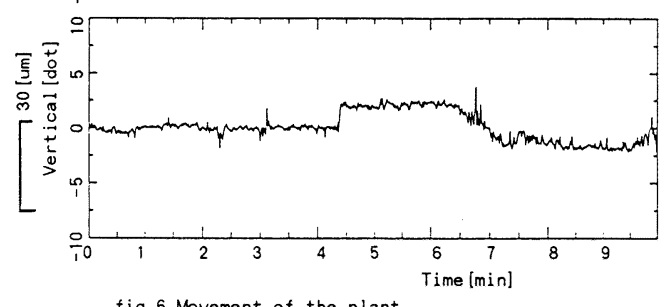

9. 6 Movement of the plant
(a) horizontal (above)

(b) vertical (below)

(1) H. Minamitani, E. Okada, et.al.: "RBC VELOCITY DISTRIBUTION IN THE MICROCIRCULATION ESTIMATED FROM THE OPTICAL FLOW OF BLOOD IMAGE SEQUENCES" Ann. Int. Conf. IEEE/EMBS, Vol. 12, No. 1, 1990

（2）南谷、他: “濃度こう配法を用いた微小血管内の 2 次元速度分布の計测” 電子情報通信学会論文誌(D-II) 1990.2

（3）山ロ:“スッペクルの性質と応用”応用物理 1977 第8号 など

（4）清水、桑島: "QuickVector の特徵と応用”映像情報 1991.10

（5）清水、桑島: “相関法を用いた画像計测システムのサブピクセル精度について” 第 3 回流体制御／計测合同シンポジゥム講演論文集（1991.12） 